удк 158.46 .75

\title{
ЗНАЧЕННЯ ТА РОЛЬ БЮДЖЕТНОГО КОНТРОЛЮ В СИСТЕМІ БЮДЖЕТНОГО ПРОЦЕСУ
}

\section{THE VALUE AND ROLE OF BUDGET CONTROL IN THE SYSTEM OF THE BUDGET PROCESS}

\author{
Іляшенко Анфіса Христофрорівна \\ доктор економічних наук, профресор, \\ Чернівецький національний університет імені Юрія Федьковича \\ ORCID: https://orcid.org/0000-0002-3046-3802
}

\author{
Iliashenko Anfisa \\ Yuriy Fedkovych Chernivtsi National University
}

\begin{abstract}
В Україні бюджетний контроль певною мірою зачіпає питання ефрективності використання бюджетних коштів в якості фрінансового менеджменту, а його результати майже не використовують при формуванні бюджетів та прийнятті управлінських рішень. Автор зазначає, що контроль за цільовим використанням бюджетних коштів, дотриманням вимог бюджетного законодавства, станом та використанням державного та комунального майна повинен стати більш дієвим, орієнтованим не лише на виявлення, але переважно на запобігання фрінансовим правопорушенням, має створювати основу для прийняття конкретних управлінських рішень. Тільки на цій основі в державному секторі може бути створена ефеективна система бюджетного контролю. Необхідність бюджетного контролю, його сутність і значення визначаються державним устроєм та Конституцією України. При аналізі Бюджетного кодексу України постає запитання про те, чи є контроль стадією бюджетного процесу. На думку автора, бюджетний контроль не $є$ самостійною стадією бюджетного процесу, оскільки він має місце на всіх стадіях бюджетного процесу і супроводжує весь процес утворення, розподілу і використання централізованого фонду грошових коштів - державного та місцевих бюджетів. В статті зазначається, що бюджетний контроль $є$ необхідною процедурою супроводження стадії складання, розгляду і затвердження Бюджетної декларації або прогнозу місцевого бюджету, складання проекту бюджету, розгляду і затвердження бюджету, виконання бюджету, а також складання, розгляду і затвердження звіту про виконання відповідного бюджету.
\end{abstract}

Ключові слова: бюджетний контроль, Конституція України, бюджетні кошти, бюджетне законодавство, державний сектор, державне фінанси.

В Украине бюджетный контроль в определенной степени затрагивает вопросы эфффективности использования бюджетных средств в качестве финансового менеджмента, а его результаты почти не используют при формировании бюджетов и принятии управленческих решений. Контроль за целевым использованием бюджетных средств, соблюдением требований бюджетного законодательства, состоянием и использованием государственного и коммунального имущества должен стать более действенным, ориентированным не только на выявление, но в основном на предотвращение фринансовых правонарушений, должен создавать основу для принятия конкретных управленческих решений. Только на этой основе в государственном секторе может быть создана эффективная система бюджетного контроля. Необходимость бюджетного контроля, его сущность и значение определяются государственным устройством и Конституцией Украины. При анализе Бюджетного кодекса Украины возникает вопрос о том, является контроль стадией бюджетного процесса. По мнению автора, бюджетный контроль не является самостоятельной стадией бюджетного процесса, поскольку имеет место на всех стадиях бюджетного процесса и сопровождает весь процесс образования, распределения и использования централизованного фонда денежных средств - государственного и местных бюджетов. В статье отмечается, что бюджетный контроль является необходимой процедурой сопровождения стадии составления, рассмотрения и утверждения Бюджетной декларации или прогноза местного бюджета, составление проекта бюджета, рассмотрения и утверждения бюджета, исполнения бюджета, а также составления, рассмотрения и утверждения отчета об исполнении соответствующего бюджета.

Ключевые слова: бюджетный контроль, бюджетные средства, бюджетное законодательство, государственный сектор, государственные финансы. 
In Ukraine, budget control brings up questions of effectiveness of the use of budget funds as financial management, and its results are almost not used in budgeting and management decisions. The author notes that control over the targeted use of budget funds, compliance with budget legislation, condition and use of state and municipal property should become more effective, focused not only on detection but mainly on prevention of financial offenses, should create a basis for specific management decisions. An effective system of budgetary control can be created only on this basis in the state sector. The need for budget control, its essence and significance are determined by the state system and the Constitution of Ukraine. When analyzing the Budget Code of Ukraine, the question arises as to whether control is a stage of the budget process. According to the author, budget control is not an independent stage of the budget process, as it takes place at all stages of the budget process and accompanies the entire process of formation, distribution and use of a centralized fund of funds - state and local budgets. The article states that budget control is a necessary procedure to support the stage of preparation, review and approval of the Budget Declaration or local budget forecast, drafting the budget, review and approval of the budget, budget execution, as well as preparation, review and approval of the report on the budget.

Keywords: budget control, Constitution of Ukraine, budget funds, budget legislation, state sector, state administration.

Постановка проблеми. Метою бюджетного контролює дотримання законності на всіх стадіях бюджетного процесу для есрективного виконання державою та адміністративнотериторіальними одиницями своїх фрункцій і завдань. Варто зазначити, що на рівні місцевих рад має місце відсутність зовнішнього бюджетного контролю, що дає змогу недбалим або недобросовісним чиновникам органів місцевого самоврядування перекладати свою відповідальність за неякісне управління на інші рівні влади. Така політика місцевої влади дискредитує саму ідею місцевого самоврядування, послаблює його соціальну значимість як ефрективного інструмента розвитку громадянського суспільства в країні.

Мета статті. Визначити роль бюджетного контролю в системі бюджетного процесу. Бюджетний контроль $€$ найважливішою фрункцією державного управління. Він охоплює всі сторони діяльності відповідних керованих об'єктів і являє собою постійне спостереження за впорядкованістю керованої системи та її станом.

Аналіз останніх досліджень і публікацій. Як засвідчили результати вивчення наукової літератури, значну увагу дослідженню ролі бюджетного контролю в системі бюджетного процесу приділяли науковці М.Ф. Базаясь, П.Ю. Буряк, О.Д. Василик, О.П. Гетманець, Н.Г. Виговська, Е.А. Вознесенський, І.К. Дрозд, Б.А. Карпінський, В.Д. Чернадчук.

Виклад основного матеріалу. За радянських часів завдання бюджетного контролю полягало не в перевірці виконання бюджету, бо бюджет не становив собою акта, що має певну фрормальну силу, а бюджетний контроль був не актом виділення коштів законодавчими органами в розпорядження виконавчої влади на певний період часу, а простим нарахуванням доходів і видатків, їх розписом.
Одним із перших декретів Радянської держави став Декрет про утворення Народного Комісаріату Державного Контролю. В кінці 1923 р. уряд утворив у складі Наркомфріну СРСР Фінансово-контрольне управління, на яке, зокрема, покладалася документальна перевірка доходів і видатків бюджету, обігових коштів, а в необхідних випадках - i матеріальних цінностей у підзвітних касах і установах.

Із середини 60-х рр. минулого століття бюджетний контроль здійснювали Верховна Рада СРСР, Верховні Ради союзних і автономних республік, місцеві ради за допомогою постійних планово-бюджетних та галузевих комісій, а також виконавчі органи - Рада Міністрів СРСР, Ради Міністрів союзних і автономних республік і виконавчі комітети місцевих Рад народних депутатів.

Деякі науковці розглядають бюджетний контроль за виконанням бюджету як обов'язкову стадію бюджетного процесу.

Так, відповідно до ч. 2 ст. 19 Бюджетного кодексу України, на всіх стадіях бюджетного процесу здійснюється контроль за дотриманням бюджетного законодавства, аудит та оцінка ефрективності управління бюджетними коштами відповідно до законодавства.

Якщо говорити про взаємозв'язок стадій бюджетного процесу i функцій управління, варто зазначити, що стадія складання Бюджетної декларації і стадія складання проекту бюджету збігаються 3 такою функцією управління, як планування і прогнозування - це лише різні підходи до управління бюджетом. Перший - процесний підхід, другий - фрункціональний. Функція контролю за бюджетом здійснюється на всіх стадіях бюджетного процесу. Функція регулювання здійснюється на всіх стадіях бюджетного процесу, а не лише на стадії виконання бюджету. 
Контроль розглядається як фрункція управління. Бюджет $€$ об'єктом управління, а суб'єкти управління бюджетом - це ті ж учасники бюджетного процесу.

Контроль представницьких органів влади передбачає їх право на:

- одержання від органів виконавчої влади, місцевих державних адміністрацій, виконавчих комітетів відповідних місцевих рад необхідних супровідних матеріалів при затвердженні бюджету;

- отримання від фрінансових органів держави оперативної інформації про виконання відповідних бюджетів;

- затвердження звіту про виконання відповідного бюджету;

- створення власних контролюючих органів (Рахункова палата, яка утворена Верховною Радою України).

Верховна Рада України в Бюджетному кодексі України встановила (ст. 109), що контроль за дотриманням бюджетного законодавства поширюється на стадії розгляду та затвердження Бюджетної декларації, розгляду і затвердження бюджету, виконання бюджету і здійснення бюджетного обліку, а також на стадію складання, розгляду і затвердження звіту про виконання відповідного бюджету.

Так, зокрема, ст. 109 Бюджетного кодексу України встановлює, що Верховна Рада України здійснює контроль за дотриманням бюджетного законодавства у процесі:

1) розгляду Бюджетної декларації;

2) розгляду проекту та прийняття закону про Державний бюджет України;

3) внесення змін до закону про Державний бюджет України;

4) виконання закону про Державний бюджет України, у тому числі шляхом заслуховування звітів про виконання Державного бюджету України;

5) розгляду річного звіту про виконання закону про Державний бюджет України;

6) використання кредитів (позик), що залучаються державою від іноземних держав, іноземних фрінансових установ і міжнародних фрінансових організацій.

При реалізації контрольних повноважень Верховною Радою України важливу роль відіграють спеціально створені нею власні контролюючі органи, а саме Рахункова палата.

Відповідно до ст. 110 Бюджетного кодексу України, до повноважень Рахункової палати належить здійснення контролю за надходженням та використанням коштів Державного бюджету України, у тому числі за утворенням, обслуговуванням і погашенням державного боргу, ефрективністю управління коштами державного бюджету, використанням коштів місцевих бюджетів у частині трансорертів, що надаються з державного бюджету.

У Лімській декларації встановлено, що управління державними фрінансами, незалежно від того, відображені вони в загальному національному бюджеті чи ні, має бути об'єктом контролю вищого контрольного органу.

Для вищих контрольних органів фрункція державного фрінансового контролю $€$ основною, тому цей контроль називають зовнішнім фрінансовим контролем. Такий контроль, по-перше, дає змогу оцінити об'єктивність представленої виконавчою владою інфрормації про підсумки виконання бюджету, достовірність прогнозу макроекономічних параметрів соціально-економічного розвитку країни і реалістичність бюджетних показників на майбутній орінансовий рік, хід реалізації державних програм і проектів. По-друге, якість одержуваної інформації здійснює безпосередній вплив на наслідки рішень, що приймаються на її основі законодавчою владою у вигляді законодавчих та інших нормативних правових актів.

На сьогодні назріла ідея виділення державного аудиту як особливого виду державного контролю, на відміну від фрінансового аудиту, який здійснює Рахункова палата. Державний аудит $є$ системою зовнішнього незалежного публічного аудиту діяльності органів державної влади щодо управління бюджетними коштами.

Проте відсутність на сьогодні у Рахункової палати повноважень щодо застосування державного примусу в разі виявлення в результаті проведення такого аудиту порушень бюджетної дисципліни не сприяє ефективності фрактичної моделі державного аудиту.

Розглядаючи державний фрінансовий контроль як фрункцію управління фрінансовими потоками, варто зауважити, що ця функція здійснюється всіма органами влади й управління незалежно від характеру їх основної діяльності. Державний фрінансовий контроль $\epsilon$ об'єктивною необхідністю відтворювального процесу, зумовленою сутністю фрінансів. Обсяг контрольної діяльності, її фрорми і методи, охоплення контрольними заходами різних галузей економіки залежать від меж сорери управління і статусу органу влади, що здійснює контрольні повноваження в межах державного фрінансового контролю.

Бюджетний контроль також здійснюють виконавчі органи державної влади та органи 
місцевого самоврядування. Так, згідно зі ст. 111 Бюджетного кодексу України, Міністерство фрінансів України здійснює контроль за дотриманням бюджетного законодавства на кожній стадії бюджетного процесу як щодо державного бюджету, так і місцевих бюджетів, якщо інше не передбачено законодавством України.

Міністерство фрінансів України в межах своїх повноважень забезпечує реалізацію єдиної державної політики у сорері контролю за дотриманням бюджетного законодавства, координує та спрямовує діяльність органів виконавчої влади, уповноважених на проведення контролю за дотриманням бюджетного законодавства, якщо інше не передбачено законодавством.

Місцеві фрінансові органи здійснюють контроль за дотриманням бюджетного законодавства на кожній стадії бюджетного процесу щодо місцевих бюджетів.

Відповідно до ст. 112 Бюджетного кодексу України, до повноважень Казначейства України щодо контролю за дотриманням бюджетного законодавства належить здійснення контролю за:

1) веденням бухгалтерського обліку всіх надходжень і витрат державного та місцевих бюджетів, крім випадку, передбаченого абзацами третім і четвертим частини другої ст. 78 цього кодексу, складанням та поданням фрінансової і бюджетної звітності;

2) бюджетними повноваженнями при зарахуванні надходжень до бюджету;

3) відповідністю кошторисів розпорядників бюджетних коштів показникам розпису бюджету;

4) відповідністю взятих бюджетних зобов'язань розпорядниками бюджетних коштів відповідним бюджетним асигнуванням, паспорту бюджетної програми;

5) відповідністю платежів взятим бюджетним зобов'язанням та відповідним бюджетним асигнуванням.

Треба зазначити, що сучасні національні фрінансово-контрольні системи більшості країн світу останнім часом зазнають значних змін, пов'язаних із впливом зовнішніх фракторів, а саме:

- посиленням процесів глобалізації та пов'язаною з ними необхідністю приведення національних систем бухгалтерського обліку і звітності, аудиту, контролінгу у відповідність до міжнародних стандартів;

- зростаючою економічною взаємозалежністю країн світу, збільшенням масштабів і різноманіття транснаціональних операцій.

- посиленням впливу громадянського суспільства і його причетність до механізмів контролю за діяльністю урядових структур на основі концепції розгляду уряду як найманого колективного керівника для всього суспільства 3 метою забезпечення адекватного життєзабезпечення населення та підзвітності своїм громадянам.

Одним із принципів бюджетної системи і бюджетного процесу $є$ принцип результативності та ефективності використання бюджетних коштів. Він передбачає, що при складанні та виконанні бюджетів учасники бюджетного процесу в межах встановлених їм бюджетних повноважень повинні виходити з необхідності досягнення заданих результатів з використанням найменшого обсягу коштів. Тому велике значення має застосування аудиту ефективності та результативності бюджетних коштів.

Аудит есрективності - це контрольно-аналітичний захід, спрямований на вдосконалення організації адміністрування державної (комунальної) власності, витрачання фрондів грошових коштів, їх економії. Основна мета аудиту ефрективності - визначення ефективності управління фрінансовими потоками та державною (комунальною) власністю, оцінка ефективності державного адміністрування, виявлення можливостей поліпшення процесу реалізації соціальних фрункцій.

Відповідно до стандартів IHTOCAI, аудит ефективності використовується в якості інструмента оцінки ефрективності, результативності й економічності бюджетних програм, їх впливу на соціально-економічне становище країни та окремих регіонів.

Аудит результативності являє собою перевірку та аналіз відповідності результатів, отриманих в ході здійснення фрінансування, критеріям, визначеним як планові завдання. Иого метою $є$ встановлення фракту виконання покладених (або заявлених) фрункцій.

Необхідність в аудиті результативності виникає 3 переходом на складання функціонального бюджету, оскільки при кошторисному порядку фрінансування немає необхідності оцінювати результат.

Висновок. Таким чином, підсумовуючи вищевказане, можемо зробити висновок про те, що бюджетний контроль існував у різні періоди становлення і розвитку нашої держави. Об'єктом бюджетного контролю є суспільні відносини на всіх стадіях бюджетного процесу, тобто складання Бюджетної декларації, проекту відповідного бюджету, розгляду і затвердження проекту бюджету, виконання бюджету і здійснення бюджетного обліку, а також складання, розгляду і затвердження звіту про виконання відповідного бюджету. 
Система контролю Рахункової палати інтегрована в основні складові бюджетного процесу i передбачає безперервний цикл контролю за виконанням бюджету кожного фрінансового року, що реалізується на трьох послідовних стадіях: стадії попереднього контролю проектів бюджетів на черговий фрінансовий рік, стадії оперативного контролю безпосередньо в ході виконання бюджетів поточного фрінансового року та стадії подальшого контролю вже виконаних бюджетів за звітний фрінансовий рік.

Рахункова палата не наділена повноваженнями щодо притягнення до відповідальності посадових осіб органів публічної влади, які є винними у здійсненні порушення бюджетної дисципліни.

Також необхідно впровадити сучасні методи оцінки ефективності бюджетних видатків 3 точки зору кінцевих цілей соціально-економічної політики, при цьому обов'язковою $€$ співмірність $з$ цими цілями досягнутих результатів.

На нашу думку, систему державного фрінансового контролю треба розглядати на основі організаційних принципів системного підходу, a саме: принципу концентрованості дій, принципу комплексності дій, принципу вирішальної ланки, принципу поетапного розвитку системи органів фрінансового контролю, принципу організаційної динамічності.

\section{СПИСОК ВИКОРИСТАНИХ ДЖЕРЕЛ:}

1. Бюджетний кодекс України від 8 липня 2010 р. № 2456-VI / Ооріційний вісник України : [збірник нормативно-правових актів]. Київ : Українська правова інсрормація, 2010. С. 9-84.

2. Гетманець О.П. Напрямки удосконалення внутрішнього бюджетного контролю. Вісник господарського судочинства. 2007. № 4. С. 91-94.

3. Лопушняк Г.С., Дем'янишин В.Г. Системи забезпечення та технології бюджетного процесу : [навч.-метод. посіб.]. Тернопіль : Економічна думка, 2006. 175 с.

4. Письменна Т. Принципи бюджетного контролю: теоретична інтерпретація та практика виконання. Світ фрінансів. 2011. № 4. С. 115-127.

5. Чернадчук В.Д. Бюджетний контроль: поняття та сутність. Підприємництво, господарство і право. 2002. № 11. С. 74-76.

\section{REFERENCES:}

1. Biudzhetnyi kodeks Ukrainy vid 8 Iypnia 2010 r. № 2456-VI / Ofitsiinyi visnyk Ukrainy: [zbirnyk normatyvnopravovykh aktiv]. Kyiv : Ukrainska pravova informatsiia, 2010. P. 9-84.

2. Hetmanets O.P. (2007) Napriamky udoskonalennia vnutrishnoho biudzhetnoho kontroliu. Visnyk hospodarskoho sudochynstva, no. 4, pp. 91-94.

3. Lopushniak H.S., Demianyshyn V.H. (2006) Systemy zabezpechennia ta tekhnolohii biudzhetnoho protsesu: [navch.-metod. posib.]. Ternopil: Ekonomichna dumka, 175 p.

4. Pysmenna T. (2011) Pryntsypy biudzhetnoho kontroliu: teoretychna interpretatsiia ta praktyka vykonannia. Svit finansiv, no. 4, pp. 115-127.

5. Chernadchuk V.D. (2002) Biudzhetnyi kontrol: poniattia ta sutnist. Pidpryiemnytstvo, hospodarstvo i pravo, no. 11 , pp. 74-76. 